\title{
Pembuatan Aplikasi Web Manajemen Laundry dan Integrasi Data dengan Web Service
}

\author{
Refika Khoirunnissa ${ }^{1)}$, R. Rizal Isnanto ${ }^{2)}$, Kurniawan Teguh Martono ${ }^{2)}$ \\ Program Studi Sistem Komputer Fakultas Teknik Universitas Diponegoro \\ Jalan Prof. Sudharto, Tembalang, Semarang, Indonesia \\ refika.nissa@student.undip.ac.id
}

\begin{abstract}
Abstrak - Selama ini banyak dari perusahaan di bidang jasa laundry masih menggunakan pencatatan secara manual seperti menggunakan buku, sehingga setiap data tidak terintegrasi secara waktu-nyata. Oleh sebab itu, perlu dibuat penelitian untuk merancang sebuah sistem terkomputerisasi yang dapat mempermudah pencatatan dan pengolahan data keuangan laundry.

Pembuatan Aplikasi Web Manajemen Laundry menggunakan bahasa pemrograman PHP, HTML, CSS, JavaScript dan basisdata MySQL sebagai tempat penyimpanan data. Aplikasi ini merupakan aplikasi yang terintegrasi dengan aplikasi melalui sebuah teknologi yang disebut web service. Aplikasi Web Manajemen Laundry dikembangkan dengan menggunakan metode RAD (Rapid Application Development) yang terdiri dari tahap perencanaan kebutuhan, proses perancangan, implementasi, dan tahap pengujian.

Dari hasil penelitian dapat disimpulkan bahwa Aplikasi Web Manajemen Laundry memiliki fitur yang berfungsi untuk mempermudah pencatatan dan pengolahan data secara akurat dan waktu-nyata. Fitur-fitur utama dari aplikasi ini diantaranya adalah pengolahan data transaksi, pengeluaran, dan laporan laba/rugi. Dalam menunjang fitur-fitur utama agar dapat bekerja dengan baik maka terdapat fitur pendukung yaitu pengolahan data pelanggan dan data pengguna aplikasi. Berdasarkan pengujian dengan menggunakan metode black-box, seluruh fungsi menu yang ada dalam aplikasi web telah berhasil dan berjalan sesuai dengan kebutuhan.
\end{abstract}

Kata Kunci: Aplikasi Web, Laundry, Manajemen Keuangan, PHP, MySQL, RAD.

\section{PENDAHULUAN}

Pada masa kini, sebagian besar masyarakat semakin merasakan informasi sebagai salah satu kebutuhan pokok disamping kebutuhan akan sandang, pangan dan papan. Hal ini telah mendorong transformasi masyarakat tradisional menjadi masyarakat informasi. Teknologi informasi dengan komputer mulai dikenal orang dan hingga saat ini sudah banyak perangkat lunak yang dapat digunakan orang sebagai alat pengolah data untuk menghasilkan informasi ${ }^{[1]}$.

Internet secara umum dipandang sebagai sumber daya informasi. Bahkan internet dipandang sebagai dunia dalam bentuk lain (maya) karena hampir seluruh aspek kehidupan di dunia nyata ada di internet seperti bisnis, hiburan, olah raga, politik dan lain sebagainya ${ }^{[2]}$. Dengan internet pelaku bisnis tidak lagi mengalami kesulitan dalam memperoleh informasi apapun, untuk menunjang aktivitas bisnisnya. Penggunaan internet dalam bisnis berubah dari fungsi sebagai alat untuk pertukaran informasi secara elektronik menjadi alat untuk aplikasi strategi bisnis, seperti: pemasaran, penjualan, dan pelayanan pelanggan ${ }^{[3]}$.

Aplikasi strategi bisnis ini dapat dimanfaatkan kepada para pelaku bisnis di bidang jasa seperti halnya jasa laundry. Pada umumnya, perhitungan laba rugi, laporan keuangan dan pendataan keluar masuk pakaian masih dilakukan dengan menggunakan kertas seperti menuliskan laporan keuangan pada sebuah buku serta menghitungnya satu per satu secara manual sehingga kemungkinan terjadinya kesalahan manusia sangat besar.

Untuk mengatasi permasalahan di atas, maka dirancanglah sebuah sistem yang bernama Aplikasi Web Manajemen Laundry. Dengan sistem ini, seluruh data manajemen keuangan laundry dapat diproses ke dalam sebuah sistem terkomputerisasi. Pengolahan laba rugi dalam manajemen keuangan pada laundry yang biasanya ditulis dalam sebuah buku dan dihitung secara manual dapat diatasi dengan menggunakan sistem yang dapat mempermudah pengolahan serta rekapitulasi laporan keuangan.

\section{LANDASAN TEORI}

\section{A. Laundry}

Usaha laundry adalah usaha yang bergerak di bidang jasa cuci dan setrika. Keberadaan jasa cuci mencuci dan setrika sudah menjadi bagian dari kebutuhan hidup manusia. Berkembangnya bisnis laundry kiloan menjadi persaingan di sektor ini menjadi semakin ketat ${ }^{[4]}$.

Salah satu upaya dalam meningkatkan kualitas layanan adalah dengan menerapkan suatu sistem pencatatan dan pengolahan data transaksi yang baik dan terstruktur sehingga semua informasi yang diperlukan dapat dihasilkan secara cepat dan akurat ${ }^{[5]}$.

\section{B. Web}

Web atau lengkapnya www (world wide web) adalah sebuah koleksi keterhubungan dokumen-dokumen yang disimpan di internet dan diakses menggunakan protokol (HTTP / HyperText Transfer Protocol). Intinya bahwa pengguna internet bisa memanfaatkan berbagai macam fasilitas informasi dengan biaya murah tanpa arus datang secara langsung ke tempatnya. Informasi atau dokuman yang diakses dapat berupa data teks, gambar, animasi, video, suara, atau kombinasi diantaranya dan bahkan komunikasi bisa dilakukan secara langsung dengan suara dan video sekaligus ${ }^{[6]}$. 


\section{PHP}

PHP adalah bahasa skrip yang kuat yang dirancang untuk memungkinkan pengembang untuk membuat aplikasi Web yang sangat cepat dan fitur MySQL adalah yang cepat, basisdata handal yang terintegrasi dengan baik dengan PHP dan cocok untuk aplikasi berbasis internet yang dinamis ${ }^{[8]}$.

\section{HTML}

Hypertext Markup Language (HTML) adalah bahasa dari World Wide Web (www) yang dipergunakan untuk menyusun dan membentuk dokumen agar dapat ditampilkan pada program browser. Tiap kali kita mengakses dokumen Web, maka sesungguhnya kita mengakses dokumen seseorang yang ditulis dengan menggunakan format HTML. Jadi HTML itu sendiri merupakan protokol yang digunakan untuk mentransfer data atau dokumen dari Web server ke browser ${ }^{[6]}$

\section{E. CSS}

CSS (Cascading Style Sheets) digunakan dalam kode HTML untuk menciptakan suatu kumpulan gaya tulisan yang terkadang dapat digunakan untuk memperluas kemampuan HTML. Dengan menggunakan CSS, anda hanya perlu mendefinisikan style sekali saja dan style akan berlaku untuk setiap sel dalam tabel ${ }^{[7]}$.

\section{F. JavaScript}

Javascript adalah bahasa skrip yang ditempelkan pada kode HTML dan diproses pada sisi klien. Dengan adanya bahasa ini, kemampuan dokumen HTML menjadi lebih luas ${ }^{[7]}$.

\section{G. Basisdata MySQL}

Basisdata adalah sekumpulan data yang terdiri dari satu atau lebih tabel yang saling berhubungan ${ }^{[9]}$. Dalam basisdata, data yang ada tidak hanya diletakkan dan disimpan begitu saja dalam sebuah media penyimpanan, akan tetapi dikelola dengan sebuah system pengaturan basisdata yang sering disebut dengan Database Management System (DBMS).

MySQL merupakan program yang dapat mengakses suatu basisdata MySQL yang berposisi sebagai server. Pada saat itu berarti program kita berposisi sebagai klien. Jadi MySQL adalah sebuah basisdata yang dapat digunakan baik sebagai klien maupun server ${ }^{[10]}$.

\section{H. Integrasi Data}

Integrasi data adalah suatu proses menggabungkan atau menyatukan data yang berasal dari sumber yang berbeda dan mendukung pengguna untuk melihat kesatuan data. Integrasi data dibutuhkan seiring dengan perkembangan organisasi dan meningkatnya bisnis proses pada institusi tersebut yang saling membutuhkan data-data dan informasi dari divisi atau unitunit yang berada pada organisasi tersebut ${ }^{[11]}$.

\section{Web Service}

Web service adalah konsep baru dalam sistem terdistribusi melalui Web yang menggunakan teknologi XML, dengan standar protokol HTTP dan SOAP. Konsep teknologi Web service muncul untuk mendukung sistem terdistribusi yang berjalan pada infrastruktur yang berbeda ${ }^{[12]}$. Data yang didapatkan dari web service dikirimkan dalam format standar misalnya XML atau JSON (Javascript Object Notation) ${ }^{[13]}$.
JSON adalah format pertukaran data yang ringan, mudah dibaca dan ditulis oleh manusia, serta mudah diterjemahkan dan dibuat oleh komputer ${ }^{[14]}$.

\section{J. Google Maps API}

Google Maps API merupakan perkembangan dari google Maps. Dengan menggunakan google Maps API ini, dimungkinkan untuk dapat menggunakan google Maps di dalam website. Meski awalnya hanya JavaScript API, Maps API diperluas untuk menyertakan sebuah API untuk aplikasi Adobe Flash. Salah satu keuntungan dari penggunaan google Maps ini adalah layanan gratis bagi para pengembang yang ingin memanfaatkan layanan google Maps tersebut ${ }^{[15]}$.

\section{K. Rapid Application Development (RAD)}

Rapid Application Development (RAD) sebagai salah satu alternatif dari System Development Life Cycle (SDLC) belakangan ini seringkali digunakan untuk mengatasi keterlambatan yang terjadi apabila menggunakan metode konvensional. Adapun keunggulan yang bisa didapatkan dengan menggunakan metode ini adalah kecepatan, ketepatan, dan biaya yang relatif lebih rendah dibanding dengan metode konvensional. Metode RAD memiliki 3 (tiga) tahapan utama seperti yang terlihat pada Gambar 1 .

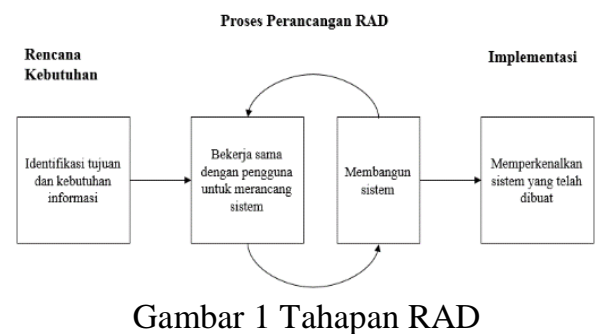

\section{Rencana Kebutuhan}

Pada tahap ini, pengguna dan analis melakukan semacam pertemuan untuk melakukan identifikasi tujuan dari aplikasi atau sistem dan melakukan identifikasi kebutuhan informasi untuk mencapai tujuan.

\section{Proses Perancangan}

Pada tahap ini adalah melakukan proses perancangan dan melakukan perbaikan-perbaikan apabila masih terdapat ketidaksesuaian perancangan antara pengguna dan analis.

\section{Implementasi}

Pada tahap ini pemrogram mengembangkan perancangan menjadi suatu program. Setelah program selesai baik itu sebagian maupun secara keseluruhan, maka dilakukan proses pengujian terhadap program tersebut apakah terdapat kesalahan atau tidak sebelum diaplikasikan pada suatu organisasi ${ }^{[16]}$.

\section{Pengujian Kotak Hitam}

Pengujian Kotak Hitam (Black Box) adalah jenis pengujian yang mengabaikan mekanisme internal dari sebuah sistem atau komponen dan hanya berfokus pada keluaran yang dihasilkan dalam menanggapi masukan yang dipilih dan kondisi eksekusi ${ }^{[17]}$.

Kotak hitam dapat menemukan kesalahan dalam kategori berikut.

1. Fungsi-fungsi yang tidak benar atau hilang 
2. Kesalahan antarmuka

3. Kesalahan dalam struktur data atau akses basisdata eksternal

4. Inisialisasi dan kesalahan terminasi

5. Validitas fungsional

6. Kesensitifan sistem terhadap nilai input tertentu

7. Batasan dari suatu data

$$
\stackrel{\text { MASUKAN }}{\longrightarrow} \text { Sistem } \stackrel{\text { PROSES }}{\longrightarrow} \begin{gathered}
\text { Analisa hanya } \\
\text { pada aspek } \\
\text { fundamental }
\end{gathered} \stackrel{\text { KELUARAN }}{\longrightarrow}
$$

Gambar 2 Sistem Kerja dari Teknik Pengujian Kotak Hitam $^{[18]}$

\section{PERANCANGAN SISTEM}

\section{A. Rencana Kebutuhan}

Aplikasi web manajemen laundry ini berfungsi untuk mengolah laporan keuangan usaha jasa laundry. Dalam mengolah laporan keuangan, aplikasi ini memiliki tiga komponen penting, yaitu pendataan keluar masuk pakaian, pendataan pngeluaran dan pengolahan laporan keuangan. Dari ketiga komponen penting tersebut komponen yang dapat dilakukan pada aplikasi web manajemen laundry yaitu pendataan pengeluaran dan pengolahan laporan keuangan. Sedangkan untuk pendataan keluar masuk pakaian dapat dilakukan pada aplikasi Android yang sudah tersedia dan terintegrasi dengan aplikasi web ini. Untuk mengintegrasikan kedua aplikasi dengan platform yang berbeda ini maka dibutuhkannya aplikasi web service. Sehingga transaksi keluar masuk barang dapat dilakukan secara waktu-nyata. Selain dari ketiga komponen penting tersebut terdapat dua komponen tambahan yaitu pendataan pelanggan yang dapat dilakukan baik di aplikasi Android maupun aplikasi web ini sendiri dan pendataan pengguna aplikasi yang hanya dapat dilakukan pada aplikasi web ini.

Dari perencanaan kebutuhan tersebut dapat digambarkan secara umum sistem aplikasi web manajemen laundry dalam bentuk sebuah bagan yang menjelaskan fungsi-fungsi apa saja yang dapat diakses atau dikerjakan oleh seorang Admin seperti ditunjukan pada Gambar 3 .

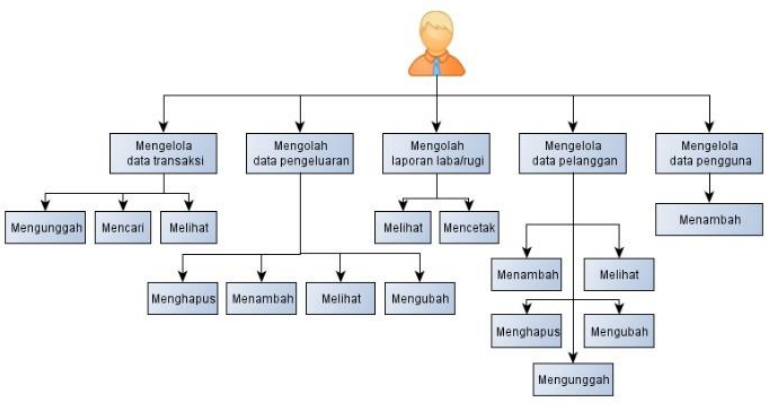

Gambar 3 Bagan Aktivitas Admin

\section{B. Proses Desain}

1. Desain Proses Kerja

Aktivitas serta perilaku aplikasi ini digambarkan dalam beberapa flowchart atau diagram alir. Diagram alir proses login ditunjukkan pada Gambar 4.

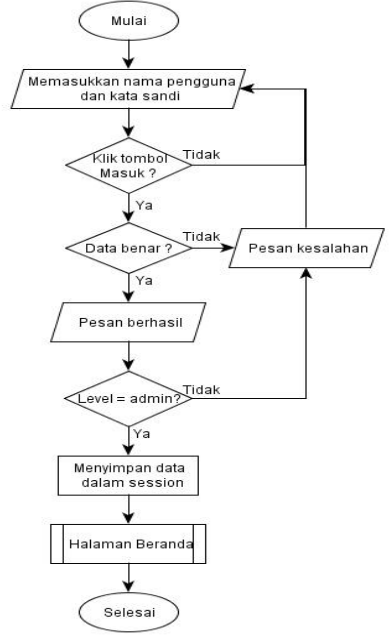

Gambar 4 Diagram Alir Proses Login

Diagram alir proses menampilkan data transaksi pakaian yang belum diantar ditunjukkan pada Gambar 5 .

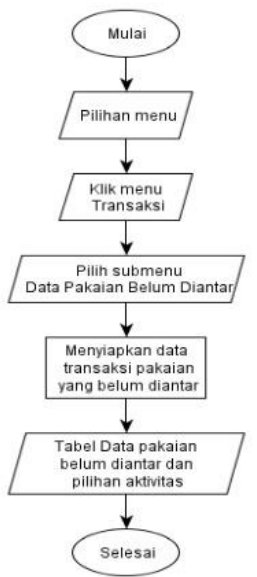

Gambar 5 Diagram Alir Data Pakaian Belum Diantar

Diagram alir proses menandai data transaksi pakaian yang telah diantar ditunjukkan pada Gambar 6.

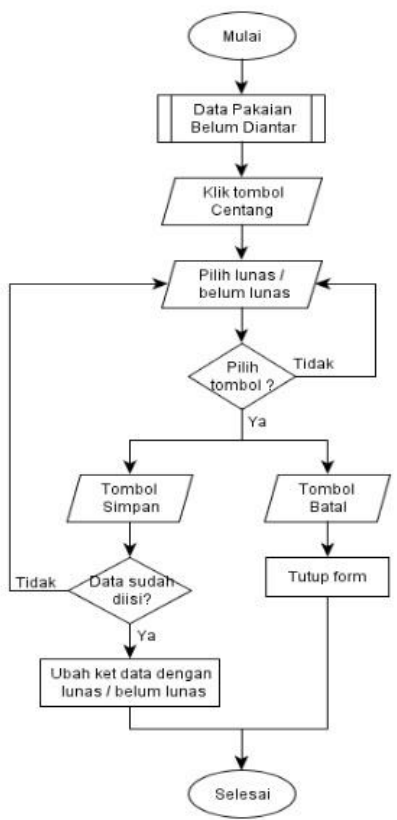

Gambar 6 Diagram Alir Data Pakaian Dikirim 
Diagram alir proses menampilkan data transaksi pakaian yang sudah diantar ditunjukkan pada Gamabr 7.

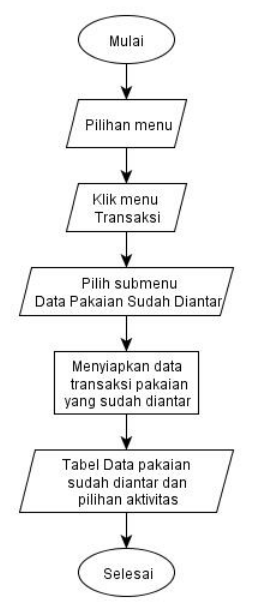

Gambar 7 Diagram Alir Data Pakaian Sudah Diantar

Diagram alir proses memasukkan data pengeluaran ditunjukkan pada Gambar 8.

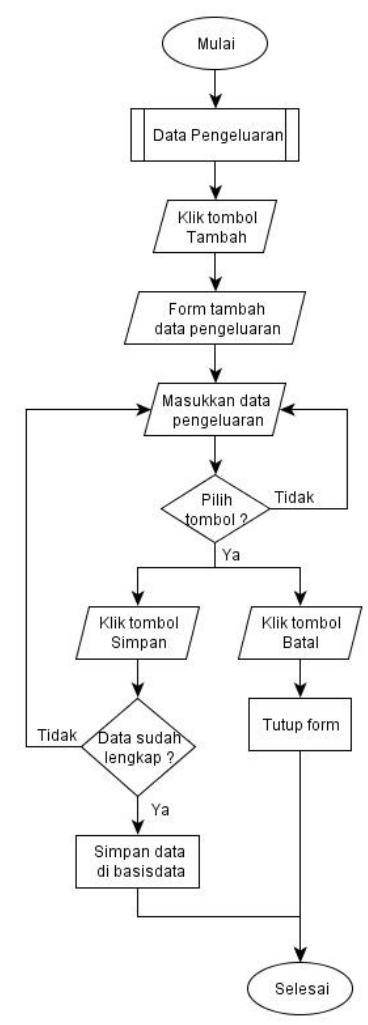

Gambar 8 Diagram Alir Tambah Data Pengeluaran

Diagram alir proses melihat laporan laba/rugi dan mencetak dalam bentuk PDF ditunjukkan pada Gambar 9.

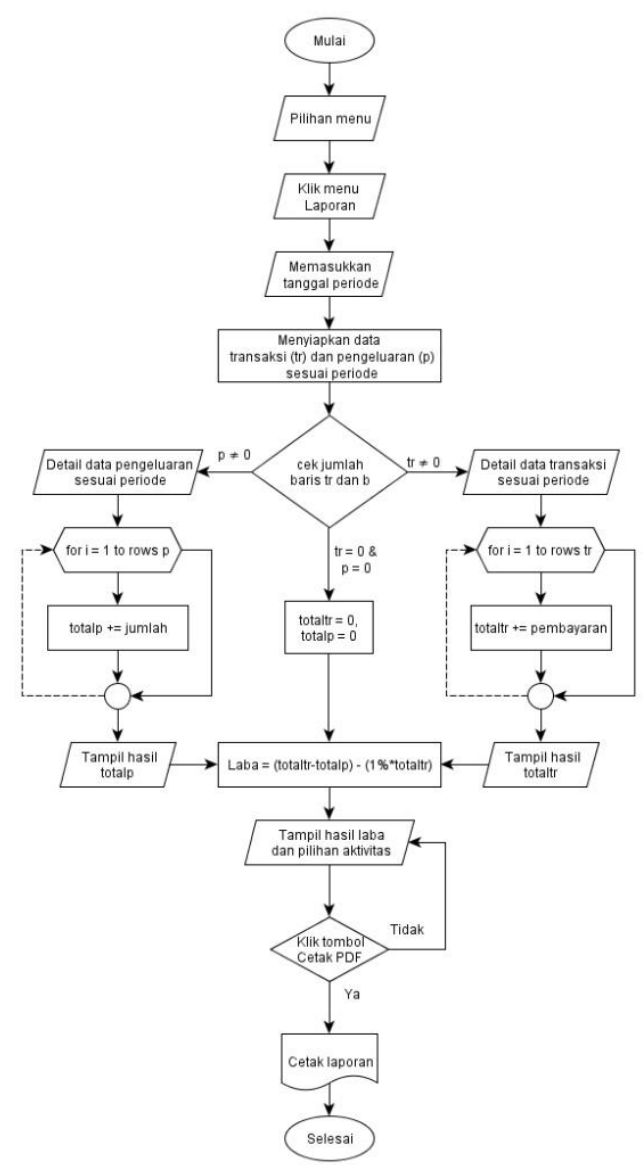

Gambar 9 Diagram Alir Laporan Laba/Rugi 10 .

Diagram alir proses logout ditunjukkan pada Gambar

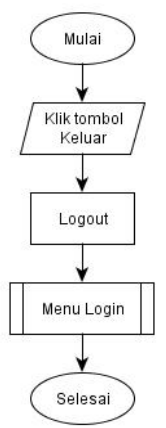

Gambar 10 Diagram Alir Proses Logout

2. Desain Basisdata

Dalam pembuatan basisdata diperlukan normalisasi basisdata sehingga tidak terjadi perulangan data yang berlebihan. Pada perancangan basisdata aplikasi web manajemen laundry membutuhkan normalisasi pada tabel data transaksi sampai pada bentuk normal ketiga 3NF. Tabel 1 menunjukkan form data transaksi sebelum dilakukan normalisasi.

Tabel 1 Bentuk Unnormal Form Data Transaksi

\begin{tabular}{|c|c|c|c|c|c|c|c|c|c|c|c|}
\hline $\begin{array}{c}\text { Kode } \\
\text { Transaksi }\end{array}$ & $\begin{array}{c}\text { MI } \\
\text { Pelanggan }\end{array}$ & $\begin{array}{c}\text { Kama } \\
\text { Pelangan }\end{array}$ & 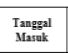 & $\begin{array}{l}\text { Tangeal } \\
\text { Kellarar }\end{array}$ & Jenis Paket & $\begin{array}{c}\text { Jumlahh } \\
\text { Cunin } \\
\text { Khuss (mit) }\end{array}$ & $\begin{array}{c}\text { Jumlah } \\
\text { Curian } \\
\text { biass }(k \text { ) }\end{array}$ & Pembayaran & Ketetrangan & ID User & Nama User \\
\hline W:300001 & 2200001 & Faridia & $2015-09-010$ & $2015-09-04$ & $\begin{array}{l}\text { Regluer Cusi } \\
\text { Sutratian }\end{array}$ & 0 & 5 & 15000 & Lunas & 3 & Boim \\
\hline Was00002 & 2200001 & Fanididia & 2015.00 .01 & $2015-09.02$ & 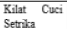 & 0 & 2 & 8000 & Lunas & 3 & Boim \\
\hline wercooos & 110005 & Allwan & $2015-09-01$ & $2015-09-04$ & $\begin{array}{l}\text { Reguler Cusi } \\
\text { Setret }\end{array}$ & 0 & 2.5 & 7500 & Lunas & 2 & Jocui \\
\hline W.300004 & 420003 & Kischthara & $2015-09-02$ & $2015-09-03$ & Kilat Cuvi & 1 & 2 & 18000 & Belumm lanas & 3 & Boim \\
\hline
\end{tabular}


Hasil normalisasi bentuk pertama atau 1NF ditunjukkan pada Tabel 2.

Tabel 2 Tabel Hasil Normalisasi 1NF Data Transaksi

\begin{tabular}{|c|c|c|c|c|c|c|c|c|c|c|c|}
\hline $\begin{array}{c}\text { Kode } \\
\text { Transalki }\end{array}$ & $\underset{\text { Pelanggan }}{\mathbb{D}}$ & 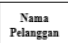 & $\begin{array}{c}\text { Tanggal } \\
\text { Massulk }\end{array}$ & $\begin{array}{l}\text { Tanggal } \\
\text { Kellarar }\end{array}$ & Jenk Pakec & 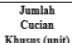 & 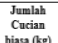 & Peabayaran & Keterangan & ID User & Nama User \\
\hline MSG00001 & 2200001 & Fanidia & $2015-09.01$ & 2015.090 .04 & 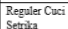 & 0 & 5 & 15000 & Inuass & 3 & Boim \\
\hline W5900002 & 2200001 & Faridiala & $2015-09-01$ & $2015-09 \cdot .02$ & $\begin{array}{l}\text { Kilat Curit } \\
\text { Sertha }\end{array}$ & a & 2 & 8000 & Iunass & 3 & Boim \\
\hline Me200003 & 110005 & Alliman & $2015-09.01$ & 2015.090 .04 & 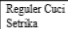 & a & 2.5 & 7500 & Iunas & 2 & Joni \\
\hline WG50004 & 4200005 & Nisakhaira & $2015-09.02$ & $2015-090.03$ & Kilat Cuwi & 1 & 2 & 18000 & Betum tunas & 3 & Boim \\
\hline
\end{tabular}

Hasil normalisasi bentuk kedua atau 2NF yang menghasilkan 3 (tiga) form ditunjukkan pada Tabel 3 - Tabel 5 .

Tabel 3 Tabel Data User Hasil Normalisasi 2NF

\begin{tabular}{|l|l|}
\hline ID User & Nama User \\
\hline 1 & Refika \\
\hline 2 & Joni \\
\hline 3 & Boim \\
\hline
\end{tabular}

Tabel 4 Tabel Data Pelanggan Hasil Normalisasi 2NF

\begin{tabular}{|l|l|}
\hline \multicolumn{1}{|c|}{$\begin{array}{c}\text { ID } \\
\text { Pelanggan }\end{array}$} & \multicolumn{1}{c|}{$\begin{array}{c}\text { Nama } \\
\text { Pelanggan }\end{array}$} \\
\hline 220001 & Fanidia \\
\hline 110005 & Alwan \\
\hline 420003 & Nisakhaira \\
\hline
\end{tabular}

Tabel 5 Tabel Data Transaksi Hasil Normalisasi 2NF

\begin{tabular}{|c|c|c|c|c|c|c|c|c|c|}
\hline $\begin{array}{c}\text { Kode } \\
\text { Transaksi }\end{array}$ & $\begin{array}{c}\text { ID } \\
\text { Pelanggan }\end{array}$ & $\begin{array}{c}\text { Tanggal } \\
\text { Masuk }\end{array}$ & $\begin{array}{c}\text { Tanggal } \\
\text { Keluar }\end{array}$ & Jenis Paket & $\begin{array}{c}\text { Jumlah } \\
\text { Cucian } \\
\text { Khusus (unit) }\end{array}$ & $\begin{array}{c}\text { Jumlah } \\
\text { Cucian } \\
\text { biasa (kg) }\end{array}$ & Pembayaran & Keterangan & ID User \\
\hline M3000001 & 220001 & $2015-09-01$ & $2015-09-04$ & $\begin{array}{l}\text { Reguler Cuci } \\
\text { Sertika }\end{array}$ & 0 & 5 & 23000 & Lunas & 3 \\
\hline M300002 & 220001 & $2015-09-01$ & $2015-09-02$ & $\begin{array}{l}\text { Kilat } \\
\text { Setrika }\end{array}$ & 0 & 2 & 23000 & Lunas & 3 \\
\hline M200002 & 110005 & $2015-09-01$ & $2015-09-04$ & $\begin{array}{l}\text { Reguluer Cuci } \\
\text { Regrtika }\end{array}$ & 0 & 2.5 & 7500 & Lunas & 2 \\
\hline M300003 & 420003 & $2015-09-02$ & $2015-09-03$ & $\begin{array}{l}\text { Kilat } \\
\text { Ketrika }\end{array}$ & 1 & 2 & 18000 & Belum lunas & 3 \\
\hline
\end{tabular}

Dari Tabel 5 menghasilkan 2 (dua) form normalisasi bentuk ketiga atau 3NF ditunjukkan pada Tabel 6 dan Tabel 7. Tabel 6 Tabel Detail Transaksi Hasil Normalisasi 3NF

\begin{tabular}{|l|l|c|c|c|c|}
\hline $\begin{array}{c}\text { Kode } \\
\text { Kransaksi }\end{array}$ & Jenis Paket & $\begin{array}{c}\text { Jumlah } \\
\text { Cucian } \\
\text { Khusus (unit) }\end{array}$ & $\begin{array}{c}\text { Jumlah } \\
\text { Cucian } \\
\text { biasa (kg) }\end{array}$ & $\begin{array}{c}\text { Harga } \\
\text { Cucian } \\
\text { Khusus }\end{array}$ & $\begin{array}{c}\text { Harga } \\
\text { Cucian } \\
\text { Biasa }\end{array}$ \\
\hline M300001 & $\begin{array}{l}\text { Reguler Cuci } \\
\text { Setrika Cua }\end{array}$ & 0 & 5 & 10000 & 3000 \\
\hline M300001 & $\begin{array}{l}\text { Kilat Cuci } \\
\text { Setrika }\end{array}$ & 0 & 2 & 10000 & 4000 \\
\hline M200002 & $\begin{array}{l}\text { Reguler Cuci } \\
\text { Setrika Cuci }\end{array}$ & 0 & 2.5 & 10000 & 3000 \\
\hline M300003 & $\begin{array}{l}\text { Kilat Cut Cuci } \\
\text { Setrika }\end{array}$ & 1 & 2 & 10000 & 4000 \\
\hline
\end{tabular}

Tabel 7 Tabel Data Transaksi Hasil Normalisasi 3NF

\begin{tabular}{|c|c|c|c|l|c|}
\hline $\begin{array}{c}\text { Kode } \\
\text { Transaksi }\end{array}$ & $\begin{array}{c}\text { ID } \\
\text { Pelanggan }\end{array}$ & $\begin{array}{c}\text { Tanggal } \\
\text { Masuk }\end{array}$ & Pembayaran & Keterangan & ID User \\
\hline M300001 & 220001 & $2015-09-01$ & 23000 & Lunas & 3 \\
\hline M200002 & 110005 & $2015-09-01$ & 7500 & Lunas & 2 \\
\hline M300003 & 420003 & $2015-09-02$ & 18000 & Belum lunas & 3 \\
\hline
\end{tabular}

Dari hasil normalisasi basisdata maka dapat dirancang gambaran kebutuhan, serta keterkaitan antar data pada basisdata, gambaran yang digunakan biasanya adalah Entity Relationship Diagram (ERD). Gambar 11 menunjukkan hubungan antara tabel data transaksi dengan data pelanggan

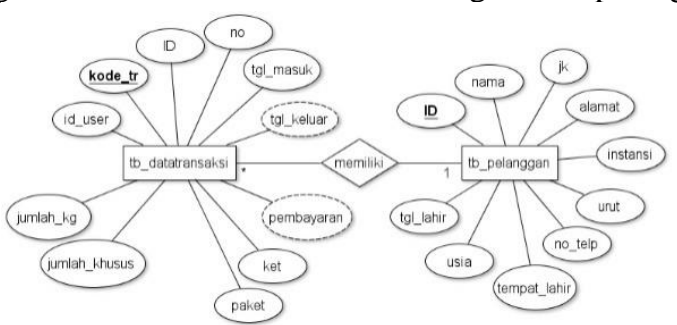

Gambar 11 ERD Data Pakaian Masuk
Pencatatan pengeluaran membutuhkan hubungan dari tabel pengeluaran dengan tabel akun yang ditunjukkan pada Gambar 12.

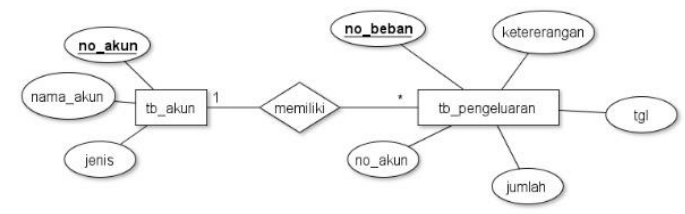

Gambar 12 ERD Pencatatan Pengeluaran

Gambar 13 menunjukkan hubungan antara tabel data transaksi dengan tabel pengeluaran yang menghasilkan laporan laba/rugi.

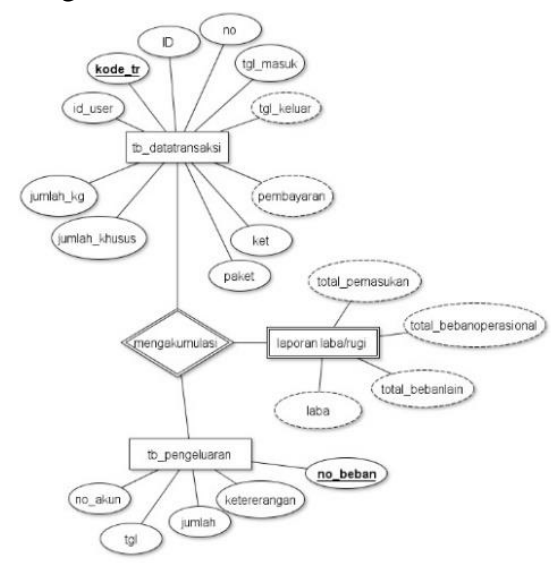

Gambar 13 ERD Laporan Laba/Rugi

3. Desain Tampilan

Desain tampilan bertujuan memberikan gambaran secara umum dari aplikasi yang akan dibangun. Gambar 14 menunjukkan desain tampilan pada halaman login.

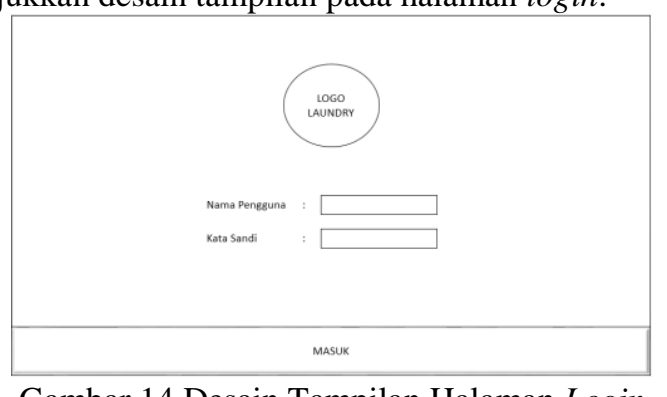

Gambar 14 Desain Tampilan Halaman Login

Gambar 15 menunjukkan desain tampilan pada menu Data Pakaian Belum Diantar.

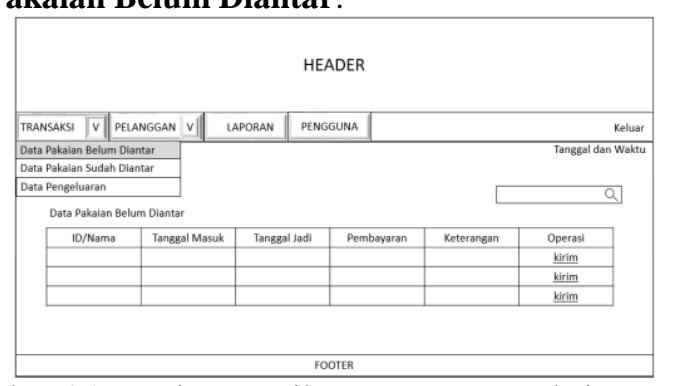

Gambar 15 Desain Tampilan Menu Data Pakaian Belum Diantar 
Menu Data Pakaian Sudah Diantar ditunjukkan pada Gambar 16.

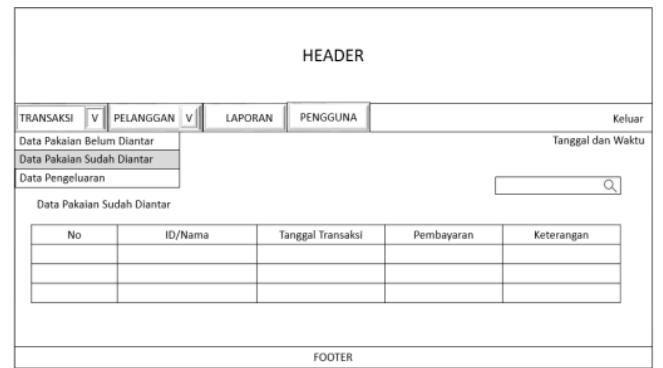

Gambar 16 Desain Tampilan Menu Data Pakaian Sudah Diantar

Gambar 17 menunjukkan desain tempilan pada menu Data Pengeluaran.

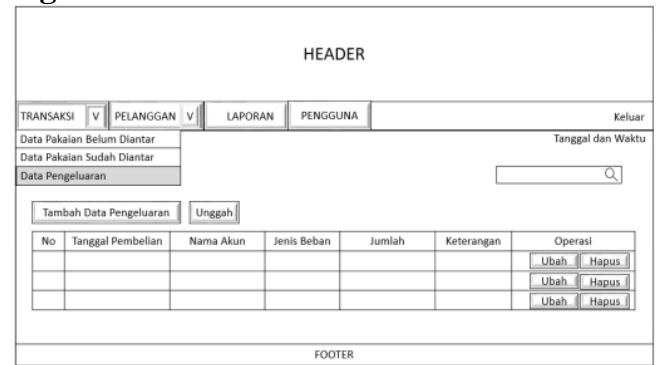

Gambar 17 Desain Tampilan Menu Data Pengeluaran

Desain tampilan menu Laporan Laba/Rugi ditunjukkan pada Gambar 18.

\begin{tabular}{|c|c|c|c|}
\hline \multicolumn{4}{|c|}{ HEADER } \\
\hline tranSANSI v pelangGan vi & LAPORAN & PENGGUNA & Keluar \\
\hline & Tanggal dan Wakta \\
\hline Periode & \begin{tabular}{|l|l|}
$P D F$ \\
\end{tabular} & & \\
\hline & Pensosion & & \\
\hline S & $\overline{\bar{~}}$ & & \\
\hline 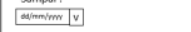 & ב & & \\
\hline & Besen uninition & & \\
\hline & $\overline{ }$ & 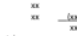 & \\
\hline & 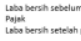 & roper & \\
\hline
\end{tabular}

Gambar 18 Desain Tampilan Menu Laporan Laba/Rugi

\section{Hasil PeneltTian DAN PEMbahasan}

\section{A. HASIL PENELITIAN}

Berikut merupakan tampilan aplikasi yang dibuat.

1. Halaman login

Halaman login adalah halaman yang pertama kali tampil ketika aplikasi web diakses. Gambar 19 menunjukkan tampilan pada halaman login.

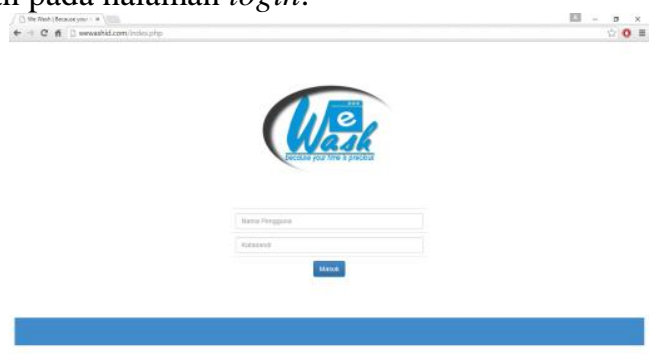

Gambar 19 Tampilan Halaman Login

2. Tampilan menu Data Pakaian Belum Diantar
Menu Data Pakaian Belum Diantar ditunjukkan pada Gambar 20 berisi data transaksi pakaian yang belum diantar. Data ditampilkan dalam sebuah tabel dengan 12 kolom yang mencakup informasi tentang detail transaksi. kolom Option berisi tombol $\sqrt{ }$ (centang) yang berguna untuk memberi tanda bahwa transaksi sudah diantar dengan pilihan status pembayaran lunas atau belum lunas seperti pada Gambar 21.

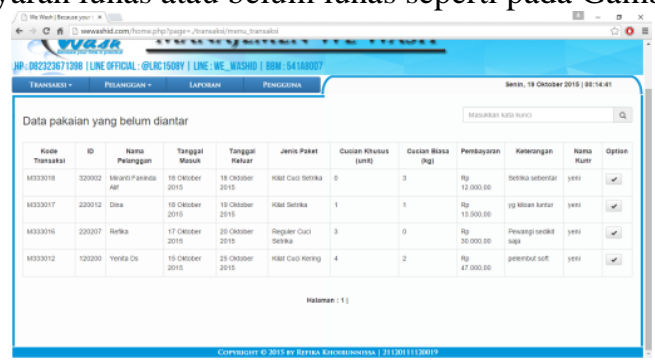

Gambar 20 Tampilan Menu Data Pakaian Belum Diantar

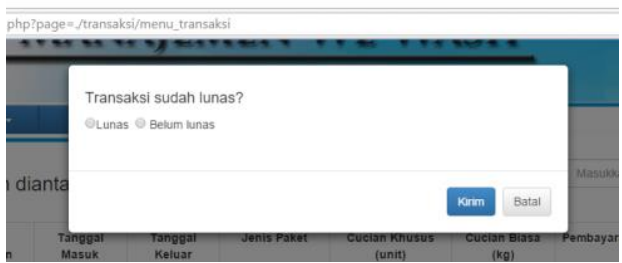

Gambar 21 Tampilan Form Antar Pakaian

3. Tampilan menu Data Pakaian Sudah Diantar

Menu Data Pakaian Sudah Diantar ditunjukkan pada Gambar 22 berisi tabel informasi data transaksi pakaian yang sudah diantar. Tabel data transaksi pakaian sudah diantar berisi 10 kolom. kolom Option terdapat tombol Ubah yang digunakan untuk merubah keterangan dari "belum lunas" menjadi "lunas" seperti pada Gambar 23 sesuai dengan status pembayaran pelanggan.

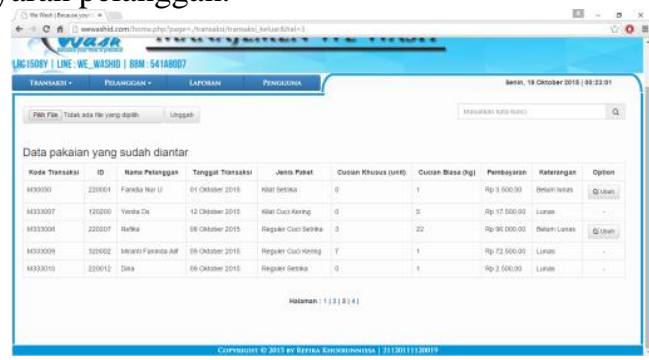

Gambar 22 Tampilan Menu Data Pakaian Sudah Diantar

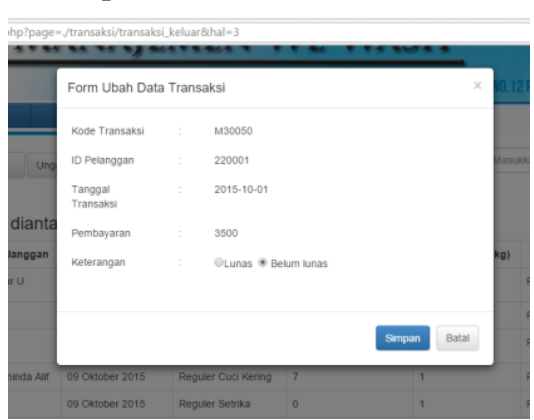

Gambar 23 Tampilan Form Ubah Data Transaksi

4. Tampilan menu Data Pengeluaran

Menu Data Pengeluaran yang digunakan untuk mengelola data pengeluaran ditunjukkan pada Gambar 24. 


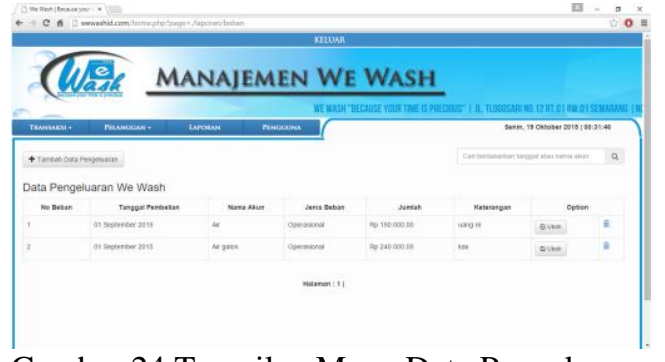

Gambar 24 Tampilan Menu Data Pengeluaran

\section{Tampilan menu Laporan}

Menu Laporan menampilkan laporan laba/rugi yang seperti terlihat pada Gambar 25. Laporan laba/rugi dapat ditampilkan sesuai dengan periode tanggal yang dimasukan oleh Admin pada sisi kiri tampilan. Laporan laba/rugi yang ditampilkan juga dapat dicetak dalam bentuk berkas berformat PDF (Portable Document Format). Gambar 26 merupakan tampilan laporan pada berkas PDF.

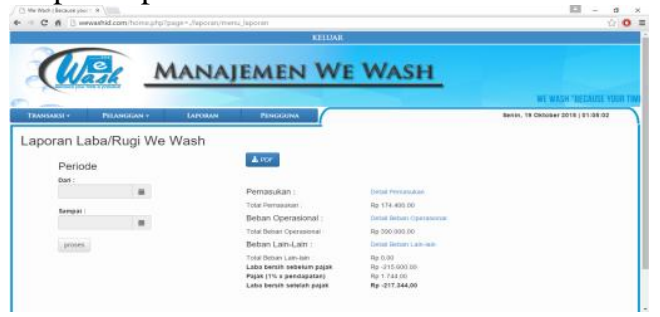

Gambar 25 Tampilan Menu Laporan

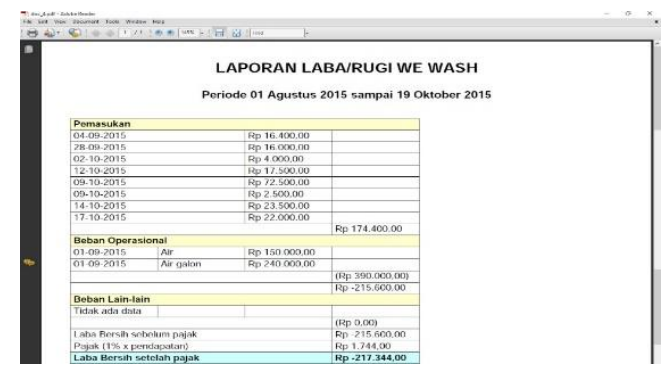

Gambar 26 Tampilan Laporan Laba/Rugi dalam Fromat PDF

6. Tampilan web service data transaksi pakaian

Tampilan web service data transaksi pakaian menggunakan format JSON seperti yang ditunjukkan pada Gambar 27.

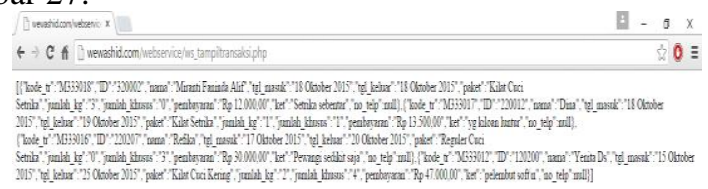

Gambar 27 Web Service Data Transaksi Pakaian

7. Tampilan webservice data pelanggan

Tampilan web service data transaksi pakaian menggunakan format JSON seperti yang ditunjukkan pada Gambar 28.

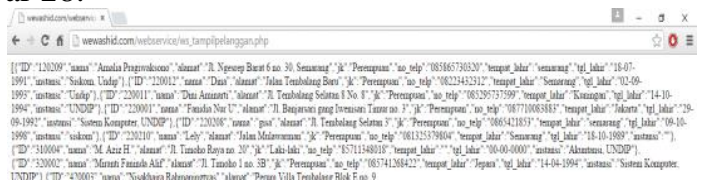

Gambar 28 Web Service Data Pelanggan
B. Pengujian Kotak Hitam

Pengujian ini dilakukan untuk menunjukkan fungsi program yang dibuat tentang cara operasi dan kegunaannya, apakah keluaran data sesuai dengan yang diharapkan. Pengujian ini dilakukan untuk mengetahui apakah masih terjadi kesalahan program atau program sudah berhasil diselesaikan dengan benar.

Pengujian aplikasi dibuat berupa tabel pengujian kotak hitam dari menu yang ada dalam aplikasi. Tabel pengujian pada menu Login ditunjukkan pada Tabel 8.

Tabel 8 Tabel Pengujian Menu Login

\begin{tabular}{|c|l|l|l|c|}
\hline No & $\begin{array}{c}\text { Skenario } \\
\text { Pengujian }\end{array}$ & Test Case & \multicolumn{1}{c|}{$\begin{array}{c}\text { Hasil yang } \\
\text { diharapkan }\end{array}$} & $\begin{array}{c}\text { Hasil } \\
\text { Pengu- } \\
\text { jian }\end{array}$ \\
\hline 1 & $\begin{array}{l}\text { Mengisi } \\
\text { kolom nama } \\
\text { pengguna dan } \\
\text { katasandi }\end{array}$ & $\begin{array}{l}\text { Mengisi } \\
\text { kolom nama } \\
\text { pengguna dan } \\
\text { katasandi }\end{array}$ & $\begin{array}{l}\text { Akan menampilkan } \\
\text { pesan "harap diisi" } \\
\text { ketika klik tombol } \\
\text { masuk di klik dan } \\
\text { kolom belum terisi }\end{array}$ & Valid \\
\hline 2 & $\begin{array}{l}\text { Pesan } \\
\text { kesalahan jika } \\
\text { katasandi } \\
\text { salah }\end{array}$ & $\begin{array}{l}\text { Klik tombol } \\
\text { Masuk } \\
\text { kesan } \\
\text { kser bukanan jika } \\
\text { seorang } \\
\text { Admin }\end{array}$ & $\begin{array}{l}\text { Akan menampilkan } \\
\text { pesan "login gagal" } \\
\text { ketika katasandi } \\
\text { tidak sesuai }\end{array}$ & Valid \\
\hline 4 & $\begin{array}{l}\text { Menampilkan } \\
\text { halaman } \\
\text { beranda } \\
\text { ketika } \text { login } \\
\text { berhasil }\end{array}$ & $\begin{array}{l}\text { Klik tombol } \\
\text { Masuk }\end{array}$ & $\begin{array}{l}\text { Mesan menampilkan } \\
\text { dapat mengakses } \\
\text { halaman ini" }\end{array}$ & Valid \\
halaman beranda & Valid \\
\hline
\end{tabular}

Tabel 9 menunjukkan pengujian akan fungsi-fungsi yang dapat dijalankan pada menu Data Pakaian Belum Diantar. Tabel 9 Tabel Pengujian Menu Data Pakaian Belum Diantar

\begin{tabular}{|c|l|l|l|c|}
\hline No & \multicolumn{1}{|c|}{$\begin{array}{c}\text { Skenario } \\
\text { Pengujian }\end{array}$} & Test Case & \multicolumn{1}{c|}{$\begin{array}{c}\text { Hasil yang } \\
\text { diharapkan }\end{array}$} & $\begin{array}{c}\text { Hasil } \\
\text { Pengu- } \\
\text { jian }\end{array}$ \\
\hline 1 & $\begin{array}{l}\text { Menampilkan } \\
\text { data transaksi } \\
\text { pakaian yang } \\
\text { belum diantar } \\
\text { urut sesuai } \\
\text { tanggal keluar } \\
\text { paling awal }\end{array}$ & $\begin{array}{l}\text { Klik tombol } \\
\text { Penu Data } \\
\text { Pakaian } \\
\text { Belum } \\
\text { Diantar }\end{array}$ & $\begin{array}{l}\text { Menampilkan data } \\
\text { transaksi pakaian } \\
\text { yang belum diantar } \\
\text { urut berdasarkan } \\
\text { tanggal keluar } \\
\text { terawal dalam } \\
\text { bentuk tabel }\end{array}$ & Valid \\
\hline 2 & $\begin{array}{l}\text { Pencarian } \\
\text { data } \\
\text { berdasarkan } \\
\text { ID pelanggan }\end{array}$ & $\begin{array}{l}\text { Memasukkan } \\
\text { pada kolom } \\
\text { pencarian }\end{array}$ & $\begin{array}{l}\text { Menampilkan data } \\
\text { transaksi pakaian } \\
\text { belum diantar milik } \\
\text { id pelanggan yang } \\
\text { dimasukkan }\end{array}$ & Valid \\
\hline 3 & $\begin{array}{l}\text { Pencarian } \\
\text { data } \\
\text { berdasarkan } \\
\text { nama } \\
\text { pelanggan }\end{array}$ & $\begin{array}{l}\text { Memasukkan } \\
\text { nama } \\
\text { pelanggan } \\
\text { pada kolom } \\
\text { pencarian }\end{array}$ & $\begin{array}{l}\text { Menampilkan data } \\
\text { transaksi pakaian } \\
\text { belum diantar milik } \\
\text { nama pelanggan } \\
\text { yang dimasukkan }\end{array}$ & Valid \\
\hline 4 & $\begin{array}{l}\text { Pencarian } \\
\text { data } \\
\text { berdasarkan } \\
\text { kode } \\
\text { transaksi }\end{array}$ & $\begin{array}{l}\text { Memasukkan } \\
\text { kode } \\
\text { transaksi } \\
\text { pada kolom } \\
\text { pencarian }\end{array}$ & $\begin{array}{l}\text { Menampilkan data } \\
\text { transaksi pakaian } \\
\text { selum diantar } \\
\text { dengan kode } \\
\text { transaksi seperti } \\
\text { yang dimasukkan }\end{array}$ & Valid \\
\hline 5 & $\begin{array}{l}\text { Klik tombol } \\
\text { centang }\end{array}$ & $\begin{array}{l}\text { Data transaksi } \\
\text { pakaian dipindah ke } \\
\text { data pakaian sudah } \\
\text { diantar }\end{array}$ & Valid \\
\hline
\end{tabular}


Menu Data Pakaian Sudah Diantar berisi data kiriman dari menu Data Pakaian Belum Diantar, adapun fungsifungsi yang dapat dijalankan diuji dalam Tabel 10 .

Tabel 10 Tabel Pengujian Menu Data Pakaian Sudah Diantar

\begin{tabular}{|c|c|c|c|c|}
\hline No & $\begin{array}{c}\text { Skenario } \\
\text { Pengujian }\end{array}$ & Test Case & $\begin{array}{l}\text { Hasil yang } \\
\text { diharapkan }\end{array}$ & $\begin{array}{c}\text { Hasil } \\
\text { Pengu- } \\
\text { jian }\end{array}$ \\
\hline 1 & $\begin{array}{l}\text { Menampilkan } \\
\text { data transaksi } \\
\text { pakaian yang } \\
\text { sudah diantar }\end{array}$ & $\begin{array}{l}\text { Kilk tombol } \\
\text { menu Data } \\
\text { Pakaian } \\
\text { Sudah } \\
\text { Diantar }\end{array}$ & $\begin{array}{l}\text { Menampilkan data } \\
\text { transaksi pakaian } \\
\text { yang sudah diantar }\end{array}$ & Valid \\
\hline 2 & $\begin{array}{l}\text { Mengunggah } \\
\text { berkas } \\
\text { dengan } \\
\text { format csv }\end{array}$ & $\begin{array}{l}\text { Klik tombol } \\
\text { Unggah }\end{array}$ & $\begin{array}{l}\text { Menyimpan isi data } \\
\text { dari berkas yang } \\
\text { diunggah dan } \\
\text { menampilkan di } \\
\text { tabel data transaksi } \\
\text { pakaian sudah } \\
\text { diantar }\end{array}$ & Valid \\
\hline 3 & $\begin{array}{l}\text { Pencarian } \\
\text { data } \\
\text { berdasarkan } \\
\text { ID pelanggan }\end{array}$ & $\begin{array}{l}\text { Memasukkan } \\
\text { id pelanggan } \\
\text { ke kolom } \\
\text { pencarian }\end{array}$ & $\begin{array}{l}\text { Menampilkan data } \\
\text { transaksi pakaian } \\
\text { sudah diantar milik } \\
\text { id pelanggan yang } \\
\text { dimasukkan }\end{array}$ & Valid \\
\hline 4 & $\begin{array}{l}\text { Pencarian } \\
\text { data } \\
\text { berdasarkan } \\
\text { nama } \\
\text { pelanggan }\end{array}$ & $\begin{array}{l}\text { Memasukkan } \\
\text { nama } \\
\text { pelanggan ke } \\
\text { kolom } \\
\text { pencarian }\end{array}$ & $\begin{array}{l}\text { Menampilkan data } \\
\text { transaksi pakaian } \\
\text { sudah diantar milik } \\
\text { nama pelanggan } \\
\text { yang dimasukkan }\end{array}$ & Valid \\
\hline 5 & $\begin{array}{l}\text { Pencarian } \\
\text { data } \\
\text { berdasarkan } \\
\text { keterangan } \\
\text { data transaksi }\end{array}$ & $\begin{array}{l}\text { Memasukkan } \\
\text { keterangan ke } \\
\text { kolom } \\
\text { pencarian }\end{array}$ & $\begin{array}{l}\text { Menampilkan data } \\
\text { transaksi pakaian } \\
\text { sudah diantar } \\
\text { dengan keterangan } \\
\text { sesuai yang } \\
\text { dimasukkan } \\
\end{array}$ & Valid \\
\hline 6 & $\begin{array}{l}\text { Pencarian } \\
\text { data } \\
\text { berdasarkan } \\
\text { kode } \\
\text { transaksi }\end{array}$ & $\begin{array}{l}\text { Memasukkan } \\
\text { kode } \\
\text { transaksi ke } \\
\text { kolom } \\
\text { pencarian }\end{array}$ & $\begin{array}{l}\text { Menampilkan data } \\
\text { transaksi pakaian } \\
\text { sudah diantar } \\
\text { dengan kode } \\
\text { transaksi sesuai } \\
\text { yang dimasukkan }\end{array}$ & Valid \\
\hline 7 & $\begin{array}{l}\text { Mengubah } \\
\text { data dengan } \\
\text { keterangan } \\
\text { "Belum } \\
\text { lunas" } \\
\text { menjadi } \\
\text { "Lunas" }\end{array}$ & $\begin{array}{l}1 . \\
\text { Klik tombol } \\
\text { Ubah } \\
2 . \\
\text { Pilih lunas }\end{array}$ & $\begin{array}{l}1 . \\
\text { Menampilkan form } \\
\text { ubah data } \\
2 . \\
\text { Mengubah } \\
\text { keterangan menjadi } \\
\text { "Lunas" }\end{array}$ & Valid \\
\hline
\end{tabular}

Pengujian terhadap fungsi-fungsi yang ada pada menu Data Pengeluaran ditunjukkan pada Tabel 11 .

Tabel 11 Tabel Pengujian Menu Data Pengeluaran

\begin{tabular}{|c|l|l|l|c|}
\hline No & $\begin{array}{c}\text { Skenario } \\
\text { Pengujian }\end{array}$ & Test Case & \multicolumn{1}{|c|}{$\begin{array}{c}\text { Hasil yang } \\
\text { diharapkan }\end{array}$} & $\begin{array}{c}\text { Hasil } \\
\text { Pengu- } \\
\text { jian }\end{array}$ \\
\hline 1 & $\begin{array}{l}\text { Menampilkan } \\
\text { data } \\
\text { pengeluaran }\end{array}$ & $\begin{array}{l}\text { Klik tombol } \\
\text { menu Data } \\
\text { Pengeluaran }\end{array}$ & $\begin{array}{l}\text { Menampilkan data } \\
\text { pengeluaran dalam } \\
\text { bentuk tabel }\end{array}$ & Valid \\
\hline 2 & $\begin{array}{l}\text { Menambah } \\
\text { data } \\
\text { pengeluaran }\end{array}$ & $\begin{array}{l}\text { Klik tombol } \\
\text { Tambah }\end{array}$ & $\begin{array}{l}\text { Data ditambahkan } \\
\text { ke basisdata }\end{array}$ & Valid \\
\hline 3 & $\begin{array}{l}\text { Pesan } \\
\text { kesalahan } \\
\text { pada kolom } \\
\text { tambah data } \\
\text { pengeluaran } \\
\text { yang belum } \\
\text { diisi }\end{array}$ & $\begin{array}{l}\text { Mengosong- } \\
\text { kan kolom } \\
\text { pada form } \\
\text { tambah data } \\
\text { pengeluaran }\end{array}$ & $\begin{array}{l}\text { Menampilkan pesan } \\
\text { "harus isi bidang ini } \\
\text { "pilih item pada } \\
\text { daftar" }\end{array}$ & Valid \\
\hline
\end{tabular}

\begin{tabular}{|c|l|l|l|c|}
\hline 4 & $\begin{array}{l}\text { Mengubah } \\
\text { data } \\
\text { pengeluaran }\end{array}$ & $\begin{array}{l}\text { Klik tombol } \\
\text { Ubah dan } \\
\text { mengubah } \\
\text { datapada } \\
\text { form ubah } \\
\text { data } \\
\text { pengeluaran }\end{array}$ & $\begin{array}{l}\text { Data dapat terubah } \\
\text { sesuai kemauan }\end{array}$ & Valid \\
\hline 5 & $\begin{array}{l}\text { Menghapus } \\
\text { data } \\
\text { pengeluaran }\end{array}$ & $\begin{array}{l}\text { Klik tombol } \\
\text { Hapus }\end{array}$ & $\begin{array}{l}\text { Data terhapus dari } \\
\text { daftar }\end{array}$ & Valid \\
\hline 6 & $\begin{array}{l}\text { Pencarian } \\
\text { data } \\
\text { pengeluaran } \\
\text { berdasarkan } \\
\text { tanggal } \\
\text { pembelian }\end{array}$ & $\begin{array}{l}\text { Memasukkan } \\
\text { tanggal } \\
\text { pembelian } \\
\text { pada kolom } \\
\text { pencarian }\end{array}$ & $\begin{array}{l}\text { Menampilkan data } \\
\text { yang sesuai dengan } \\
\text { pencarian }\end{array}$ & Valid \\
\hline 7 & $\begin{array}{l}\text { Pencarian } \\
\text { data } \\
\text { pengeluaran } \\
\text { berdasarkan } \\
\text { nama akun }\end{array}$ & $\begin{array}{l}\text { Memasukkan } \\
\text { nama akun } \\
\text { pada kolom } \\
\text { pencarian }\end{array}$ & $\begin{array}{l}\text { Menampilkan data } \\
\text { yang sesuai dengan } \\
\text { pencarian }\end{array}$ & Valid \\
& & \\
\hline
\end{tabular}

Pengujian terhadap fungsi-fungsi yang ada pada menu Laporan ditunjukkan pada Tabel 12.

Tabel 12 Tabel Pengujian Menu Laporan

\begin{tabular}{|c|l|l|l|c|}
\hline No & $\begin{array}{c}\text { Skenario } \\
\text { Pengujian }\end{array}$ & Test Case & \multicolumn{1}{c|}{$\begin{array}{c}\text { Hasil yang } \\
\text { diharapkan }\end{array}$} & $\begin{array}{c}\text { Hasil } \\
\text { Pengu- } \\
\text { jian }\end{array}$ \\
\hline 1 & $\begin{array}{l}\text { Menampilkan } \\
\text { laporan } \\
\text { laba/rugi }\end{array}$ & $\begin{array}{l}\text { Memilih } \\
\text { tanggal } \\
\text { periode }\end{array}$ & $\begin{array}{l}\text { Menampilkan } \\
\text { laporan laba/rugi }\end{array}$ & Valid \\
\hline 2 & $\begin{array}{l}\text { Mencetak } \\
\text { laporan } \\
\text { laba/rugi }\end{array}$ & $\begin{array}{l}\text { Klik tombol } \\
\text { PDF }\end{array}$ & $\begin{array}{l}\text { Mencetak laporan } \\
\text { dalam bentuk berkas } \\
\text { berformat pdf }\end{array}$ & Valid \\
\hline
\end{tabular}

Dari hasil pengujian yang telah dilakukan pada fungsifungsi yang ada pada setiap menu dalam aplikasi web manajemen laundry ini maka dapat disimpulkan bahwa aplikasi ini sudah layak digunakan dalam pengelolaan data manajemen laundry karena setiap pengujian yang dilakukan menunjukkan indikasi berhasil seperti apa yang diharapkan.

\section{PENUTUP}

A. Kesimpulan

Dari hasil pengujian dan analisis terhadap aplikasi web manajemen laundry dan integrasi data dengan web service ini dapat disimpulkan beberapa hal-hal berikut.

1. Aplikasi web manajemen laundry merupakan aplikasi berbasis website yang memiliki fitur inti berupa pengolahan data transaksi, pengeluaran, dan laporan laba/rugi, sehingga dapat mempermudah pekerjaan manajemen laundry yang sebelumnya dilakukan secara manual.

2. Aplikasi web manajemen laundry juga memiliki fitur tambahan berupa pengolahan data pelanggan dan data user atau pengguna aplikasi.

3. Pengujian yang dilakukan pada aplikasi ini menggunakan metode blackbox atau kotak hitam dan memperoleh hasil valid di setiap pengujian fungsifungsi pada aplikasi, sehingga dapat disimpulkan bahwa fungsi-fungsi yang ada sudah sesuai dengan kebutuhan sistem. 
B. Saran

Saran yang diberikan dalam upaya pengembangan sistem yang lebih baik dikemudian hari diantaranya.

1. Perlu dikembangkan aplikasi pada sisi pelanggan yang memuat fitur-fitur pemesanan laundry dan informasi deposit pelanggan.

2. Perlu dilakukan penelitian lanjutan untuk membandingkan kinerja basisdata yang dapat menyimpan data dengan skala besar.

\section{DAFTAR PUSTAKA}

[1] Maharsi, S, "Pengaruh Perkembangan Teknologi Informasi Terhadap Bidang Akuntansi Manajemen," $J$. Akunt. dan Keuang., vol. 2, no. 2, pp. 127-137, 2000.

[2] Wibowo, A. T., "Pembuatan Aplikasi E-Commerce Pusat Oleh-Oleh Khas Pacitan," pp. 62-67, 2013.

[3] Yuliana, O, "Penggunaan Teknologi Internet dalam Bisnis," J. Akunt. dan Keuang., vol. 2, pp. 36-52, 2000.

[4] Suprayogi, D. A., dan Mahmudy, W. F., "Penerapan Algoritma Genetika Traveling Salesman Problem with Time Window: Studi Kasus Rute Antar Jemput Laundry," J. Buana Inform., vol. 6, no. 2, pp. 121-130, 2014.

[5] Tanto, I, "Sistem Informasi Jasa Laundry Pada PT . Tiara Panca Abadi," no. 18, 2000.

[6] Supriyanto, A, Web dengan HTML dan XML. Yogyakarta: Graha Ilmu, 2007.

[7] Kadir, A, Pemrograman Web Mencakup: HTML, CSS, JavaScript dan PHP. Yogyakarta: ANDI, 2003.

[8] Thomson, L, dan Welling, L, PHP and MySQL Web development. 2005.

[9] MADCOMS, Aplikasi Manajemen Database Pendidikan Berbasis Web dengan PHP dan MySQL. Madiun: ANDI, 2005.

[10] Nugroho, B, Database Relasional dengan MySQL. Yogyakarta: ANDI, 2005.

[11] Sugiarto, M dan Fajarhati, P, "Implementasi Integrasi Data Antar Sistem Informasi Untuk Mendukung Decission Support System," vol. 2008, 2008.

[12] Deviana, H, "Penerapan XML Web service Pada Sistem Distribusi Barang," vol. 6, no. 2, 2011.

[13] Raditia, M, dan Surendra, S, "Implementasi PHP Web Service Sebagai Penyedia Data Aplikasi Mobile," vol. VI, no. 2, pp. 85-93, 2014.

[14] PENG, D, CAO, L, dan XU, W, "Using JSON for data exchanging in web service applications," J. Comput. Inf. Syst., vol. 7, no. 16, pp. 5883-5890, 2011.

[15] Masykur, F, "Implementasi sistem informasi geografis menggunakan google maps api dalam pemetaan asal mahasiswa," J. SIMETRIS, vol. 5, no. 2, pp. 181-186, 2014.
[16] Noertjahyana, A, "Studi Analisis Rapid Aplication Development Sebagai Salah Satu Alternatif Metode Pengembangan Perangkat Lunak," J. Inform., vol. 3, no. 2, pp. 64-68, 2002.

[17] Khanna, E, Bhasin, H, dan Sudha, "Black Box Testing based on Requirement Analysis and Design Specifications," vol. 87, no. 1, pp. 36-40, 2014.

[18] Rouf, A, "Pengujian perangkat lunak dengan menggunakan metode white box dan black box," pp. 17, 2012. 